\title{
COMMENT
}

\section{The militarization of anti-poaching: undermining long term goals?}

\section{Introduction}

The illegal wildlife trade has become increasingly sophisticated and poaching of wildlife, including elephants and rhinoceros, is rising (Burn et al. 2011; Biggs et al. 2013; Wittemyer et al. 2014). The London Declaration, signed in February 2014 by 46 countries, calls for four basic actions to tackle the problem: eradicating markets for illegal wildlife products; ensuring effective legal frameworks and deterrents; strengthening law enforcement; and promoting sustainable livelihoods and development. It backs these with a $£ 10$ million fund from the UK Government. The Declaration proposes a broad palette of action, but that breadth is threatened by growing calls for stronger armed responses to poaching from a wide range of conservation non-governmental organizations (NGOs, including leading international organizations) and national governments (including the US Government; White 2014; Duffy 2015). We argue that these calls could be counter-productive because they are founded on limited knowledge about poverty and poaching, inadequately address rising wealth in user markets (Ayling 2013; Roe et al. 2014), make oversimplified claims that trafficking is funding terrorism (White 2014), and do not adequately consider demand reduction strategies.

\section{The shifting drivers of poaching}

Poaching is changing because of changing patterns of wealth in demand countries, the dynamics of poverty in supply countries and the interplay between them. In debates about the relationships between poverty, poaching and conservation, there is an underlying assumption that the poor poach to raise their income in situations where they have limited alternatives (Roe 2008). Poaching cannot be understood merely as a response to material deprivation. It is also driven by prestige, identity and custom (MacDonald 2004). Attempts to combat poaching through livelihood enhancement that do not engage with these realities will founder (Alexander \& McGregor 2000). If it is assumed that poverty drives poaching, we must also recognize that poverty is multidimensional, encompassing lack of power, prestige, voice, and an inability to shape one's future (Sen 1999; Hulme 2010).

Recent increases in poaching are more closely related to increases in wealth in demand countries, rather than poverty in supply countries. Recent reports from CITES (2014) and
TRAFFIC (Milliken \& Shaw 2012) suggest that new drivers of the illegal wildlife trade are part of a shift from traditional culture-related consumption to new forms of conspicuous consumption driven by rising incomes. In the 1980s and 1990s, key markets for rhino horn were Taiwan, Yemen, and to a lesser extent, China. Rhino horn was primarily used in traditional Chinese medicine (TCM) as a cardio-tonic and blood thinner (rather like aspirin in Western medicine) and as jambiyya dagger handles in Yemen (a marker of status). The market for horn in Yemen has reduced because of economic decline there, and, following a national ban, Taiwan no longer has a significant market (Milliken \& Shaw 2012; Ayling 2013). Now, the rising markets are in Vietnam and China: as wealth increases a greater number of people can afford to purchase products that contain rhino horn. However, this only provides part of the explanation. Certainly, in Vietnam, increased demand is also linked to new patterns of consumption and groups of consumers. Prior to 2006, use of rhino horn in Vietnam was limited. However, demand increased following the comments of a prominent politician who thought it alleviated his cancer (Rademeyer 2012, pp. 275). The price of rhino horn in Vietnam in 2013 was US\$ $65000 \mathrm{~kg}^{-1}$, and sometimes US $\$ 75000 \mathrm{~kg}^{-1}$ (Ayling 2013, pp. 60). Rhino horn also began to be used as a form of conspicuous consumption as a 'party drink' that did not result in a hangover and was thought to fortify male strength. Although never originally an aphrodisiac (which was a Western myth), that myth has now gone full circle and Vietnamese consumers now refer to it in these terms (Rademeyer 2012, pp. 274-276). In late 2014, the Humane Society International claimed that consumption of rhino horn had reduced by 33\% partly as a result of their campaigns, however this was based on a small study and Vietnam remains the biggest market for rhino horn (Humane Society International 2014). Clearly then, the demand in Vietnam blends rising incomes, historical health practices, emerging cultural norms, conspicuous consumption, and state-level corruption (Milliken \& Shaw 2012; Ayling 2013; Litchfield 2013).

\section{Anti-poaching as a global security initiative}

Appropriate policy responses to these threats may be impeded by the ways that poaching is linked to issues of global security. A good example is the link drawn between poaching and Al Shabaab, which can be traced back to a single investigation by the Elephant Action League (Kalron \& Crosta 2012; see also White 2014). Posted on the Elephant Action 
League website in 2012, their report was only picked up by international media after the attacks on Nairobi's Westgate Mall in 2013. Since then, claims linking Al Shabaab to wildlife trafficking have been made in diverse fora, including testimonial to the US Senate Committee on Foreign Relations (US Senate Committee on Foreign Relations 2012), the UK's Chatham House (Lawson \& Vines 2014), meetings of the International Conservation Caucus Foundation (Barron 2013) and media reports (Doshi 2014). More broadly, Hilary Clinton (US Secretary of State 2009-2013) and Barack Obama (US President 2009-present) have made public statements drawing links between wildlife trafficking, poaching and global security (Goldenberg 2013; The White House 2013). The idea that ivory poaching funds terrorism thus circulates in high political circles, but it does so on a paucity of clear evidence and using simplifications of a complex political economy of poaching. Somali groups have long been identified as a possible source of ivory poaching in Kenya, while, at the same time, poaching activities have also been linked to corruption within the Kenyan Government itself (Leakey \& Morell 2002).

These simplifications matter because where militias and insurgent groups are involved in ivory poaching, it is only part of a wider military strategy, and hence so must counter-poaching strategies. Poaching has been used as a financial underpinning for conflicts across Sub-Saharan Africa, including Uganda in the 1970s and 1980s, Angola and Mozambique in the 1980s, the Great Lakes region since 1996, and the Central African Republic and its neighbours more recently (Ellis 1994; Humphreys \& Smith 2011). Solutions to poaching must engage with issues of broader regional stability and the wider political context (Milburn 2012; Lunstrum 2014).

There are also serious ethical concerns. More forceful actions against poaching can lead to injustices (Neumann 2004); this was an important omission in Challender and MacMillan's (2014) review of poaching and policy responses, which did not examine how more aggressive approaches to enforcement are made possible by policy debates. Shoot-to-kill policies are legal in some states (such as Botswana and Uganda), contrary to the principles of the Conservation Initiative on Human Rights (CIHR), to which many in the conservation community aspire (IIED [International Institute for Environment and Development] 2015).

\section{Undermining long-term goals}

Strong and forceful approaches to conservation can work (Brockington 2002). Specifically, there is evidence that greater levels of patrolling reduced poaching in the Serengeti (Hilborn et al. 2006). However, the same authors were clear that their analyses did not provide evidence that better armed rangers, or greater use of force, would be more effective. Instead, militarized approaches can escalate conflict between rangers and poachers, and lead to the alienation of local communities.

Arresting more poachers does not always stop criminal syndicates. In South Africa, rhino poaching continued to rise despite increased arrests (Milliken \& Shaw 2012; Rademeyer 2012; Standley \& Emslie 2013). Where poaching is the consequence of organized criminal networks and global commodity chains, tackling just one end of the chain will have limited impact (Rademeyer 2012; Duffy et al. 2013). We need to be cognizant of the fact that the illegal wildlife trade is not a singular phenomenon that requires a onesize-fits-all strategy to tackle it. Illegal hunting and wildlife trading play a central role in the subsistence strategies of many communities around the world (Roe et al. 2014). The strategies for tackling subsistence hunting need to be quite different to those for commercial-scale poaching of high-value products. Other approaches seek to reduce demand in enduser markets (Zain 2012) as an effective strategy. There are arguments in favour of formal legalization and monitoring of wildlife trades (such as the rhino horn trade; Biggs et al. 2013), but these do not adequately address important considerations of the relative roles of wealth, poverty and inequality. Clearly, different trades might require very different policy responses according to species, place of origin, trade and transit route, and profile of demand.

\section{Conclusion}

The breadth of the London Declaration is welcome. A key issue is what sort of impact it makes on policy and practice, based on the types of understandings of the problem. Important measures of success will include the long-term solutions that it fosters, and the extent to which it tackles poaching within the broader political, social and economic context of which it is part. Efforts to reduce poaching need to engage with the broader political economy of the wildlife trade; notably how wealth (rather than poverty) drives demand, and structures markets and trade. Reducing demand from consumers needs a complex combination of carefully-designed awareness campaigns, leadership from involved actors, and systems of incentives and penalties. Previous experience indicates this will require commitments over several decades from all stakeholders, not just greater enforcement in supply countries.

\section{References}

Alexander, J. \& McGregor, J. (2000) Wildlife and politics: CAMPFIRE in Zimbabwe. Development and Change 31: 605627.

Ayling, J. (2013) What sustains wildlife crime? Rhino horn trading and the resilience of criminal networks. Journal of International Wildlife Lam and Policy 16: 57-80.

Barron, D. (2013) US Congressional international conservation caucus hearing. International Conservation Caucus 
Foundation, Washington, DC, USA [www document]. URL https://www.youtube.com/watch? $\mathrm{v}=$ lVThOf5lB78

Biggs, D., Courchamp, F., Martin, R. \& Possingham, H.P. (2013) Legal trade of Africa's rhino horns. Science 339: 10381039 .

Brockington, D. (2002) Fortress Conservation. The Preservation of the Mkomazi Game Reserve, Tanzania. Oxford, UK: James Currey.

Burn, R.W., Underwood, F.M. \& Blanc, J. (2011) Global trends and factors associated with the illegal killing of elephants: a hierarchical bayesian analysis of carcass encounter data. PLoS ONE 6: e24165.

Challender, D. \& MacMillan, D.C. (2014) Poaching is more than an enforcement problem. Conservation Letters 7: 484 494.

CITES (2014) CITES meets as 'wealth' is replacing 'health' as a driver of wildlife consumption [www document]. URL http://www.cites.org/eng/CITES_SC65_wealth_replacing_ health_as_driver_of_wildlife_consumption

Doshi, V. (2014) Elephant campaign: how Africa's 'white gold' funds the al-Shabaab militants. The Independent, London, UK [www document]. URL http://www.independent.co.uk/voices/ campaigns/elephant-campaign/elephant-campaign-how-africaswhite-gold-funds-the-alshabaab-militants-9102862. html

Duffy, R. (2015) War by conservation. Geoforum (in press).

Duffy, R., Emslie, R.H. \& Knight, M.H. (2013) Rhino poaching: how do we respond? Report. Evidence on Demand with the assistance of the UK Department for International Development (DFID) [www document]. URL http://www.evidenceondemand.info/rhino-poaching-how-dowe-respond

Ellis, S. (1994) Of elephants and men: politics and nature conservation in South Africa. Fournal of Southern African Studies 20: 53-69.

Goldenberg, S. (2013) Hillary and Chelsea Clinton unveil $\$ 80 \mathrm{~m}$ effort to fight illegal ivory trade. The Guardian, London, UK [www document]. URL http://www.theguardian.com/world/2013/ sep/26/hillary-chelsea-clinton-african-elephants-ivorypoaching

Hilborn, R., Arcese, P., Borner, M., Hando, J., Hopcraft, G., Loibooki, M., Mduma, S. \& Sinclair, A.R.E. (2006) Effective enforcement in a conservation area. Science 314: 1266 .

Hulme, D. (2010) Global Poverty: How Global Governance is Failing the Poor. London, UK and New York, NY, USA: Routledge.

Humane Society International (2014) Word is spreading in Viet Nam: rhino horn isnt medicine [www document]. URL http://www.hsi.org/news/news/2014/10/vietnam-rhino-horndemand-reduced-poll-101614.html

Humphreys, J. \& Smith, M.L.R. (2011) War and wildlife: the Clausewitz connection. International Affairs 87: 121142.

IIED (2015) Conservation initiative on human rights. IIED, London, UK [www document]. URL http://www.iied.org/ conservation-initiative-human-rights

Kalron, N. \& Crosta, A. (2012) Africa's white gold of Jihad: alShabaab and conflict ivory. Elephant Action League, CA, USA [www document]. URL http://elephantleague.org/project/ africas-white-gold-of-jihad-al-shabaab-and-conflict-ivory/

Lawson, K. \& Vines, A. (2014) Global impacts of the illegal wildlife trade: the costs of crime, insecurity and institutional erosion. Report. Chatham House, London, UK [www document]. URL http://www.chathamhouse.org/sites/files/chathamhouse/ public/Research/Africa/0214Wildlife.pdf

Leakey, R. \& Morell, V. (2002) Wildlife Wars: My Battle to Save Kenya's Elephants. London, UK: Pan Books.

Litchfield, C.A. (2013) Rhino poaching: apply conservation psychology. Science 340: 1168.

Lunstrum, E. (2014) Green organization: anti-poaching efforts and the spatial contours of Kruger National Park. Annals of the Association of American Geographers 104: 816832.

MacDonald, K. (2004) Developing 'nature': global ecology and the politics of conservation in northern Pakistan. In: Confronting Environments: Local Environmental Understanding In a Globalising World, ed. J. Carrier, pp. 71-96. Lanham, MD, USA: AltaMiraPress.

Milburn, R. (2012) Mainstreaming the environment into postwar recovery: the case for 'ecological development. International Affairs 88: 1083-1100.

Milliken, T. \& Shaw, J. (2012) The South Africa-Viet Nam rhino horn trade nexus: a deadly combination of institutional lapses, corrupt wildlife industry professionals and Asian crime syndicates. Report. TRAFFIC, Johannesburg, South Africa [www document]. URL www.traffic.org/species-reports/ traffic_species_mammals66.pdf

Neumann, R.P. (2004) Moral and discursive geographies in the war for biodiversity in Africa. Political Geography 23: 813837.

Rademeyer, J. (2012) Killing for Profit: Exposing the Illegal Rhino Horn Trade. Cape Town, South Africa: Zebra Press.

Roe, D. (2008) The origins and evolution of the conservation-poverty debate: a review of key literature, events and policy processes. Oryx 42: 491-503.

Roe, D., Milledge, S., Cooney, R., 't Sas-Rolfes, M., Biggs, D., Murphree, M. \& Kasterine, A. (2014) The elephant in the room: sustainable use in the illegal wildlife trade debate. IIED Policy Briefing, London, UK [www document]. URL http://pubs.iied.org/pdfs/17205IIED.pdf

Sen, A. (1999) Development As Freedom. Oxford, UK: Oxford University Press.

Standley, S. \& Emslie, R.H. (2013) Population and poaching of the African rhinos across African range states. Report. Evidence on Demand with the assistance of the UK Department for International Development [www document]. URL http://www. evidenceondemand.info/population-and-poaching-of-africanrhinos-across-african-range-states

The White House (2013) Fact sheet: US efforts to combat wildlife trafficking. Office of the Press Secretary,Washington, DC, USA [www document]. URL http://www.whitehouse.gov/ the-press-office/2013/07/01/fact-sheet-us-efforts-combatwildlife-trafficking

US Senate Committee on Foreign Relations (2012) Ivory and insecurity: the global implications of poaching in Africa. Report. US Government Printing Office, Washington, DC, 
USA [www document]. URL http://www.gpo.gov/fdsys/pkg/ CHRG-112shrg76689/pdf/CHRG-112shrg76689.pdf

White, N. (2014) The 'White Gold of Jihad': violence, legitimisation and contestation in anti-poaching strategies. Fournal of Political Ecology 21: 452-474.

Wittemyer, G., Northrup, J.M., Blanc, J., Douglas-Hamilton, I., Omondi, P. \& Burnham, K.P. (2014) Illegal killing for ivory drives global decline in African elephant. Proceedings of the National Academy of Sciences USA 111: 1311713121.

Zain, S. (2012) Behaviour change we can believe in: towards a global demand reduction strategy for tigers. Report. TRAFFIC International, Cambridge, UK [www document]. URL www.traffic.org/species-reports/traffic_species_mammals71.pdf
ROSALEEN DUFFY ${ }^{1 *}$, FREYA A. V. ST JOHN ${ }^{2}$, BRAM BÜSCHER ${ }^{3}$ AND DAN BROCKINGTON ${ }^{4}$

${ }^{l}$ Department of Development Studies, SOAS, University of London, Thornhaugh Street, Russell Square, London WC1H OXG, UK, ${ }^{2}$ Durrell Institute of Conservation and Ecology, University of Kent, Canterbury, Kent CT2 7NR, UK, ${ }^{3}$ Sociology of Development and Change Group, Wageningen University, Hollandsmeg 1, Wageningen $6706 K N$, The Netherlands and ${ }^{4}$ Institute for Development Policy and Management, School of Environment, Education and Development, The University of Manchester, Arthur Lemis Building, Oxford Road, Manchester M13 9PL, UK

*Correspondence: Professor Rosaleen Duffy e-mail: rd38@soas.ac.uk 